\title{
Body Mass Index and Body Weight Perception among a Population of Female Adolescents
}

\author{
Siham Lghoul*, Mohamed Loukid, Mohames Kamal Hilali \\ Department of Biology, Human Ecology Laboratory, Faculty of Sciences Semlalia, Cadi Ayyad University, Morocco
}

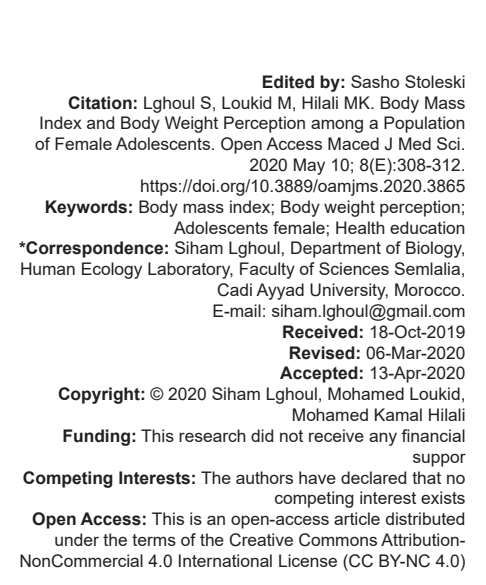

Introduction

Adolescence is a crucial time in the profound development of physical and psychological health [1]. The study of weight issues among adolescents is very important because the prevalence of weight concern and weight control increase becomes more important during adolescence. According to epidemiological studies, the overweight increases with age and seems to originate in adolescence, particularly among girls [2].

Body weight perception refers to the personal evaluation of one's weight as "underweight" or "normal weight" or "overweight" irrespective of actual body mass index (BMI) [3], [4]. Body weight dissatisfaction refers to an incorrectly judge of the current teenagers body size [5], [6].

Globally, the perception may be positive or negative and is greatly influenced by sociodemographic and environmental factors [7]. Several studies have demonstrated that body image dissatisfaction occurring during late childhood and adolescence is associated with increased negative effect [8]. In childhood, and especially in adolescence, lots of self-esteem problems arise streaming from the changes the body experiences during these years. This, combined with the natural desire of being accepted, makes children and adolescents compare themselves constantly with others. In fact, it has been demonstrated that body image is one of the most influential predictors of self-esteem [9].

The previous studies have been identified the factors associated to body weight perception. These include socioeconomic status, weight, age, sex, weight control behavior, and advice that individuals received from family members and peers [10]. Other studies have been demonstrated the association between weight body dissatisfaction and unhealthy eating behavior, anxiety, and depression among adolescents [11].

Adolescents dissatisfied with their body weight commonly report more complaints of psychological health problems such as difficulty to sleep at night, feeling nervous, stressed or depressed, having low self-esteem, and low quality of life [12]. Obesity and overweight can be linked to the distortion and dissatisfaction with body image. In fact, excessive preoccupation concern appearance and relentless desire for a prefect lean body, generate negative feelings and devaluation. This leads to a change in eating behavior, leading to overweight or the development of eating disorders [13]. On the other hand, a more positive image perception is very important in the prevention of health problems such as obesity, depression, and eating disorders [14]. 
Knowing self-perceived body weight is very important for psychological and general health because misperception may potentially affect adolescents to adopt unhealthy lifestyle. In fact, there are not enough studies, especially in North African countries, that investigated the agreement between different measurements of self-perceived body weight according to BMI. The aim of this study was to evaluate the relationships between weight self-perception and current BMI.

\section{Subjects and Methods}

Across-sectional study was based on the public schools (from February 2017 to May 2017). This study was conducted in five different middle and secondary schools of the Marrakesh city; the choice of the schools was made randomly. Participants were recruited using randomly sampling method. The study was performed on a sample of 415 school girls aged between 12 and 19 years. All participants were informed about the procedure and aims of this study and they were assured that all information obtained are confidential and secure. They had responded to our study voluntary, and their anonymity was assured by assessing each of them by a code number useful in analysis process. The questionnaire was completed by an interview during the physical activities course. Ethical permission from high educational institutions (Regional Academic of Teaching and Education and The Regional Direction of Teaching and Education) was taken; we had obtained also the authorization of school principals. Consent was required from all participants including in our study.

The questionnaire included sociodemographic information (e.g., age, age at menarche), anthropometrics measures, physical activity, school category (from middle to high school), and weight perception questions adapted from Brener et al. [15].

The weight and height were taken using the standard anthropometric methods of the International Society for the Advancement of Kinanthropometry. The weight of each girl was measured to nearest 0.1 $\mathrm{kg}$ using a balance weighing (ADE mechanical floor scale), the participant wearing light sportive cloths. The height was measured to nearest $0.5 \mathrm{~cm}$ using a body meter (Seca 206), the participant was bare feet and was standing upright. The BMI was obtained from the ratio of the weight $(\mathrm{kg})$ to the square of the height $(\mathrm{m})$.

We had calculated the BMI and the BMI percentile values were obtained using the WHO AnthroPlus software V.1.0.2 (WHO, Geneva, Switzerland). According to the CDC growth chart weight, status was defined as: $\mathrm{BMI}<5^{\text {th }}$ percentile: Underweight; $\mathrm{BMI} \geq 5^{\text {th }}$ and $<85^{\text {th }}$ percentile: Normal weight; $\mathrm{BMI} \geq 85^{\text {th }}$ and $<95^{\text {th }}$ percentile: Overweight; and $\mathrm{BMI} \geq 95^{\text {th }}$ percentile: Obese [16]. In our study, the effective of obese adolescents was low, so all participants with $\mathrm{BMI} \geq 85^{\text {th }}$ percentile were considered as overweight.

Identification of body weight perception was assured by a simple question: How do you describe yourself? Participant's responses were underweight, normal weight, overweight, and obese. In our study, we had considered "overweight" and "obese" as "overweight."

\section{Data analysis}

Our data were analyzed by SPSS (version 22). We had done a descriptive analysis (frequencies and percentage); test Chi-deux, univariate analysis were utilized to evaluate associations between variables. Logistic regression analysis was utilized to estimate the predictors of body weight misconception (dissatisfaction).

\section{Results}

Table 1 provides the descriptive characteristics of the overall sample. The mean age and age at menarche were successively $15.61 \pm 2.06$ and $12.86 \pm 1.32$ years. The mean BMI was $21.39 \pm$ $4.10 \mathrm{~kg} / \mathrm{m}^{2}$. Percentile BMI calculated revealed $5.5 \%$ to be underweight and $23.6 \%$ to be overweight; however, $75.9 \%$ perceived themselves as underweight and $8.4 \%$ perceived themselves as overweight. More than half of participants were not actives (65.5\%).

Table 1: Descriptive characteristics of the sample

\begin{tabular}{ll}
\hline Indicators demographics and anthropometrics & Female adolescents $(\mathrm{n}=415)$ \\
\hline Age (years, mean, SD) & $15.61 \pm 2.06$ \\
Age at menarche* $($ years, mean, SD) & $12.86 \pm 1.32$ \\
Weight (kg, mean, SD) & $54.01 \pm 11.49$ \\
Height $(\mathrm{m}, \mathrm{MEAN}, \mathrm{SD})$ & $158.67 \pm 6.48$ \\
BMI $\left(\mathrm{kg} / \mathrm{m}^{2}\right.$, mean, SD) & $21.39 \pm 4.10$ \\
School category $(\mathrm{n}, \%)$ & \\
$\quad$ Middle school & $177(42.6)$ \\
$\quad$ High school & $238(57.3)$ \\
BMl for age percentile $(\mathrm{n}, \%)$ & \\
$\quad$ Underweight $\left(<5^{\text {th }}\right)$ & $23(5.5)$ \\
$\quad$ Normal weight $\left(\geq 5^{\text {th }}\right.$ and $\left.<85^{\text {th }}\right)$ & $294(70.8)$ \\
Overweight $\left(\geq 85^{\text {th }}\right)$ & $98(23.6)$ \\
Weight perception category $(\mathrm{n}, \%)$ & \\
$\quad$ Underweight & $315(75.9)$ \\
Normal weight & $65(15.7)$ \\
Overweight & $35(8.4)$ \\
Physical activity $(\mathrm{n}, \%)$ & \\
Yes & $143(34.5)$ \\
No & $272(65.5)$ \\
\hline${ }^{*}$ Menarcheal girls $(\mathrm{n}=284)$. &
\end{tabular}

Table 2 shows a significant difference in currently analysis of BMI percentile and body weight perception $(p<0.001)$. In fact, all participants who were actually underweight perceived themselves as underweight, and only $24.5 \%$ who were actually overweight perceived themselves as overweight.

To assess the association of BMI percentile and body weight perception, we had categorized this association 
into tree classes: Underestimation, consistency, and overestimation (Figure 1). The prevalence of misconception was $60 \%$. Among participants, $57.5 \%$ overestimated their weight and $2.9 \%$ underestimated their weight. Participants with normal weight and overweight were less likely to judge correctly their body weight $(p<0.001)$.

Table 2: Currently analysis of BMI percentile and body weight perception

\begin{tabular}{lllll}
\hline Weight perception & $<5^{\text {th }}(\%)$ & $\geq 5^{\text {th }}$ and $<85^{\text {th }}(\%)$ & $\geq 85^{\text {th }}(\%)$ & $\mathrm{p}$ \\
\hline Underweight & $23(100)$ & $255(86.7)$ & $37(37.8)$ & $\mathrm{p}<0.001$ \\
Normal weight & $0(0)$ & $28(9.5)$ & $37(37.8)$ & \\
Overweight/obese & $0(0)$ & $11(3.7)$ & $24(24.5)$ & \\
\hline
\end{tabular}

Table 3 shows globally that more than half of the participants had misconception of their body weight $(60 \%)$. We can notice a positive correlation between the chronological age and weight perception judge ( $p<0.001)$, in fact, younger participants were the most satisfied with their body weight while participants with higher BMI were the more dissatisfied ( $p<0.001)$.

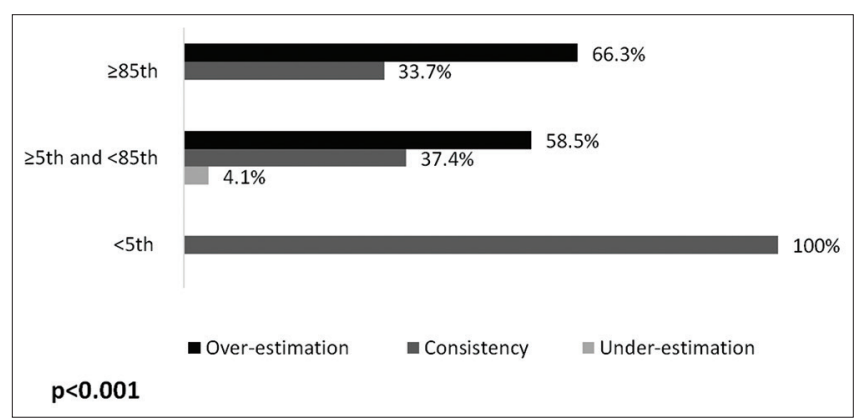

Figure 1: Consistency of body mass index percentile and body weight perception

Body weight dissatisfaction found among participants with overweight $(66.3 \%)$ and among participants with normal weight $(62.6 \%)$. However, we can notice that all participants with underweight were satisfied with their current weight (correct perception). Menarcheal girls had higher body weight dissatisfaction $(66.3 \%)$ compared to no menarcheal girls (36\%). We can notice also that the more participants were dissatisfied with their diet, the less they were satisfied with their body weight $(p<0.05)$.

Table 3: Statistics descriptive and association between variables and body weight perception

\begin{tabular}{|c|c|c|c|c|c|}
\hline \multirow[t]{2}{*}{ Variables } & \multicolumn{2}{|c|}{$\begin{array}{l}\text { Misconception } \\
\text { (dissatisfaction) }\end{array}$} & \multicolumn{2}{|c|}{$\begin{array}{l}\text { Correct perception } \\
\text { (satisfaction) }\end{array}$} & \multirow[t]{2}{*}{$p$-value } \\
\hline & Mean (SD) & $n(\%)$ & Mean (SD) & $n(\%)$ & \\
\hline Age (years) & $16.09(1.92)$ & $249(60)$ & $14.90(2.07)$ & $166(40)$ & $p<0.001^{*}$ \\
\hline $\begin{array}{l}\text { Age at menarche } \\
\text { (years) }\end{array}$ & $12.83(1.34)$ & $218(66.3)$ & $12.93(1.3)$ & $111(33.7)$ & $p=0.196$ \\
\hline $\mathrm{BMI}\left(\mathrm{kg} / \mathrm{m}^{2}\right)$ & $22.35(3.13)$ & $249(60)$ & $19.94(4.88)$ & $166(40)$ & $p<0.001^{*}$ \\
\hline$<5^{\text {th }}$ & & $0(0)$ & & $23(100)$ & $p<0.05^{\star}$ \\
\hline$\geq 5^{\text {th }}$ and $<85^{\text {th }}$ & & $184(62.6)$ & & $110(37.4)$ & $X^{2}=36.95$ \\
\hline$\geq 85^{\text {th }}$ & & $65(66.3)$ & & $33(33.7)$ & \\
\hline \multicolumn{6}{|l|}{ Menarche } \\
\hline Yes & & $218(66.3)$ & & $111(33.7)$ & $p<0.05^{*}$ \\
\hline No & & $31(36)$ & & $55(64)$ & $X^{2}=25.93$ \\
\hline \multicolumn{6}{|l|}{ Physical activity } \\
\hline Yes & & $89(62.2)$ & & $54(37.8)$ & NS \\
\hline No & & $160(58.8)$ & & $112(41.2)$ & \\
\hline \multicolumn{6}{|c|}{ Eating habits satisfaction } \\
\hline Not at all & & $31(70.5)$ & & $13(29.5)$ & $\begin{array}{l}p<0.05^{*} \\
X^{2}=10.38\end{array}$ \\
\hline Little satisfied & & $41(59.4)$ & & $28(40.6)$ & \\
\hline $\begin{array}{l}\text { Moderately } \\
\text { satisfied }\end{array}$ & & $90(67.7)$ & & $43(32.3)$ & \\
\hline $\begin{array}{l}\text { Absolutely } \\
\text { satisfied }\end{array}$ & & $87(51.5)$ & & $82(48.5)$ & \\
\hline
\end{tabular}

Figure 2 shows participants the main envisaged methods for managing their body weight. We found that the more weight increase, the more participants wanted to lose their weight, the less they wanted to keep or gain their weight $(p<0.001)$. In fact, we can notice that the most participants with overweight wanted to lose weight (68.4\%), but the most participants with underweight wanted to gain more weight $(52.2 \%)$.

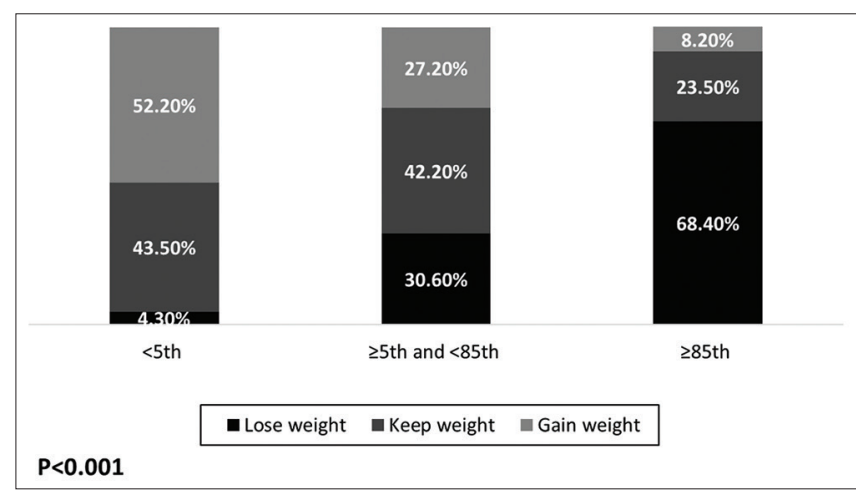

Figure 2: Consistency of body mass index percentile and envisaged manage methods

To determine the predictor factors of body weight misconception, we made a logistic regression analysis (Table 4). We found that BMI and chronological age were the predictor factors of body weight dissatisfaction.

Table 4: Associated factors for body weight misconception by simple logistic regression model

\begin{tabular}{llll}
\hline Variables & Regression coefficient $(\mathrm{b})$ & Ecart standard & $\mathrm{p}$-value \\
\hline BMl & -0.126 & 0.031 & $0.000^{*}$ \\
Age & -0.166 & 0.073 & $0.023^{*}$ \\
Menarche & -0.288 & 0.356 & 0.419 \\
Eating satisfaction & 0.064 & 0.114 & 0.571 \\
\hline${ }^{*}:$ Statistically significant result & &
\end{tabular}

\section{Discussion}

In general, the present study determined the proportion of body weight dissatisfaction and the associated factors among school girls aged 12-19 years old. We found that more than half of the participant reported dissatisfaction with their body weight, an observation that was more frequent among menarcheal and older girls, overweight or obese girls and those who were dissatisfied with their diet.

Compared to their BMI percentile, the majority of adolescents had inaccurate body weight perception. This finding was in agreement with other studies that found children and adolescents underestimated their body weight [17] or have inaccurate body weight perception when compared to their BMI [18]. Another study involving 6863 Chinese adolescents found that girls more often considered themselves to be heavier [19].

The present study showed that girls with underweight express totally body weight satisfaction compared to those with normal weight or with excess 
weight (overweight and obese). This result is supporting by other studies showed that female adolescents would express less dissatisfaction when they were underweight but more dissatisfaction when their weight was normal and most dissatisfaction when they had excess body weight [20], [21]. It was also demonstrated that adolescents with higher BMI were at higher risk of developing body image dissatisfaction compared to underweight and normal weight adolescents [22], [23]. The previous studies reported also a lower discordant weight perception among younger adolescents' girls [24], [25]. In fact, female adolescents are more likely to be exposed to thin ideal internalization through media, which has been proven influence body image, which have contributed to their body image disturbance [26], [27].

In the present study, body weight misconception has been shown to increase with age, this can be related to the physiological changes in body shape and self-esteem brought on by puberty [28]. This result is also similar to the finding of a Brazilian study that reported dissatisfaction was more frequent among older girls [25]. As they go through puberty, adolescents develop fat deposits on their body that are associated with changes in their body shape and increase in BMI, which has a significant influence on their body image [28]. On the other hand, sociocultural pressures that favor thinness as the ideal have a strong effect on body image, especially among adolescent [26]. However, another study determined that body weight dissatisfaction was not associated to age, but it was associated to BMI and sex [7].

In relation to physical activity, our study does not support most published finding suggest that being physically active is associated with better overall satisfaction [25], [29].

Our study demonstrated that participants dissatisfied with their eating develop misconception with their body weight. In the same line, it had proved that the problem with body image dissatisfaction may lead to multiple psychological problems, such as eating disorders with unhealthy dieting and binge eating [27]. According to a study conducted in the USA, a four-fold increased incidence of eating disorders was observed among female adolescents with body dissatisfaction [30], [31].

\section{Conclusion}

Relatively the half of participants had misconception with their body weight. Having an adequate and healthy body weight represent a very important challenge for girls, so maintain and manage body weight must be more improving. On the other hand, knowing the factors of body image dissatisfaction can help girls to have a healthy weight. Therefore, we should take necessary measures to improve programs on healthy lifestyle to prevent worsening of body image dissatisfaction and to correct misconceptions regarding body image and to encourage physical activity programs to predict overweight and obesity.

\section{Limitations}

For evaluating the relationship between BMI percentile and body weight perception, further studies are needed and should include more participants considering urban and rural area for both girls and boys. They must also take in consideration others parameters such as nutritional characteristics, socioeconomic level, and psychological symptoms.

\section{Acknowledgment}

Authors are very grateful to all girls who participated in this study. They also thank the Regional Academic for Teaching and Education, to the Regional Direction for Teaching and Education, and to the principals of schools visited.

\section{References}

1. Pesa JA, Syre TS, Jones EE. Psychosocial differences associated with body weight among fermale adolescents: The importance of body image. J Adolesc Health. 2000;26(5):330-7. https://doi.org/10.1016/s1054-139x(99)00118-4 PMid:10775825

2. Mokhtar N, Elati J, Chabir R, Bour A, Elkari K, Scholossman NP et al. Diet culture and obesity in Northern Africa. J Nutr. 2001;131(3):887-92. https://doi.org/10.1093/jn/131.3.887s PMid:11238780

3. Tremblay L, Limbos M. Body image disturbance and psychopathology in children: Research evidence and implications for prevention and treatment. Curr Psychiatry Rev. 2009;5(1):62-72. https://doi.org/10.2174/157340009787315307

4. Cheung P, Ip P, Lam ST, Bibby H. A study on body weight perception and weight control behaviours among adolescents in Hong Kong. Hong Kong Med J. 2007;13(1):16-21.

PMid:17277387

5. Markland D, Ingledew DK. The relationship between body mass and body image and relative autonomy for exercise among adolescent males and females. J Sport Exerc Psychol. 2007;8(5):836-53. https://doi.org/10.1016/j. psychsport.2006.11.002

6. Bogt TT, Van Dorsselaer S, Monshouwer K, Verdurmen J, Engels R, Vollebergh W. Body mass index and body weight perception as risk factors for internalizing and externalizing problem behavior among adolescents. J Adolesc Health. 2006;39(1):27-34. https://doi.org/10.1016/j. jadohealth.2005.09.007

7. Latiff AA, Muhamad J, Rahman RA. Body image dissatisfaction and its determinants among young primary-school 
adolescents. J Taibah Univ Sci. 2018;13(1):34-41. https://doi. org/10.1016/j.jtumed.2017.07.003

8. Ferreiro F, Seoane G, Senra C. Toward understanding the role of body dissatisfaction in the gender differences in depressive symptoms and disordered eating: A longitudinal study during adolescence. J Adolesc. 2014;37(1):73-84. https://doi. org/10.1016/j.adolescence.2013.10.013

PMid:24331307

9. Chacón R, Zurita F, Castro M, Espejo T, Martinez AM, Linares M. Estudio sobre la aplicabilidad de exergames para la mejora de los índices de obesidad y la imagen corporal en escolares. Rev Ibe-Roamericana Psicol Ejercicio Deporte. 2014;11(1):97-105. https://doi.org/10.1016/j.ramd.2014.10.062

10. Moreno JA, Cervello E, Moreno R. The importance of physicalsport practice and gender in physical self-concept from up to 23 years. Int J Clin Health Psychol. 2008;8(1):171-83.

11. Pon JJ, Kandiah M, Nasir MT. Body image perception, dietary practices and physical activity of overweight and normal weight Malaysian female adolescents. Malays J Nutr. 2004;10(2):131-47.

PMid:22691735

12. Forsen ME, Bergsten K, Birgegard A. Self-image and eating disorder symptoms in normal and clinical adolescents. Eat Behav. 2014;15(1):125-31. https://doi.org/10.1016/j. eatbeh.2013.11.008 PMid:24411765

13. Cecon RS, Franceschini SC, Peluzio MC, Hermsdorff $\mathrm{HH}$, Priore SE. Overweight and body image perception in adolescents with triage of eating disorders. Sci World J. 2017;2017:8257329. https://doi.org/10.1155/2017/8257329

14. Prado MC, Prado WL, De Piano A, Damaso AR. Obesidade e transtornos alimentares: A coexistencia de comportamentos alimentares extremos em adolescentes. ConSci Saude. 2011;10(3):579-85. https://doi.org/10.5585/conssaude. v10i3.2559

15. Brener ND, Eaton DK, Lowry R, McManus T. The association between weight perception and BMI among high school students. Obes Res. 2004;12(11):1866-74. https://doi. org/10.1038/oby.2004.232

PMid: 15601984

16. International Society for the Advancement of Kinanthropometry. International Standard for Anthropometric Assessment. Underdale, SA: International Society for the Advancement of Kinanthropometry; 2001.

17. National Centre for Health Statistics. National Centre for Chronic Disease Prevention and Health Promotion. Louisiana: National Centre for Health Statistics; 2000.

18. Veldhuis J, Te Poel F, Pepping R, Konijn EA, Spekman ML. Skinny is prettier and normal: I want to be normal: Perceived body image of non-Western ethnic minority children in the Netherlands. Body Image. 2017;20:74-86. https://doi. org/10.1016/j.bodyim.2016.11.006

PMid:28006714

19. Khambalia A, Hardy LL, Bauman A. Accuracy of weight perception, life-style behaviours and psychological distress among overweight and obese adolescents. J Paediatr Child Health. 2012;48(3):220-7. https://doi. org/10.1111/j.1440-1754.2011.02258.x PMid:22417463

20. Xie B, Chou CP, Spruijt-Metz D, Reynolds FC, Palmer PH, Gallaher, $\mathrm{P}$ et al. Weight perception and weight-related sociocul-tural and behavioral factors in Chinese adolescents. Prev Med. 2006;42(3):229-34. https://doi.org/10.1016/j. ypmed.2005.12.013
PMid:16458956

21. da Cunha Feio Costa L, Silva DA, Alvarenga MS, Vasconcelos FD. Association between body image dissatisfaction and obesity among schoolchildren aged $7 \mathrm{e} 10$ years. Physiol Behav. 2016;160:6-11.

PMid:27018753

22. Pelegrini $A$, Coqueiro RS, Beck $C C$, Ghedin $K D$, Lopes $A D$, Petroski EL, et al. Dissatisfaction with body image among adolescent students: Association with socio-demographic factors and nutritional status. Cien Saude Colet. 2014;19(4):1201-8. https://doi.org/10.1590/1413-81232014194.09092012 PMid:24820603

23. Wahida ZF, Nasir MT, Hazizi AS. Physical activity, eating behaviour and body image perception among young adolescents in Kuantan, Pahang, Malaysia. Malays J Nutr. 2011;17(3):325-36.

PMid:22655454

24. Bahreynian M, Qorbani M, Motlagh ME, Heshmat R, Ardalan G, Kelishadi R. Association of perceived weight status versus body mass index on adherence to weight-modifying plan among Iranian children and adolescents: The CASPIAN-IV study. Indian Pediatr. 2015;52(10):857-63. https://doi.org/10.1007/ s13312-015-0732-9

PMid:26499009

25. Park E. Overestimation and underestimation: Adolescents weight perception in comparison to BMI-based weight status and how it varies across socio-demographic factors. J Sch Health. 2011;81(2):57-64. https://doi. org/10.1111/j.1746-1561.2010.00561.x

PMid:21223272

26. Moehlecke M, Blume CA, Cureau FV, Kieling C, Schaan BD. Self-perceived body image, dissatisfaction with bodyweight and nutritional status of Brazilian adolescents: A nationwide study. J Pediatr. 2020;96(1):76-83. https://doi.org/10.1016/j. jped.2018.07.006

PMid:30098939

27. Chang FC, Lee CM, Chen PH, Chiu CH, Pan YC, Huang TF. Association of thin-ideal media exposure, body dissatisfaction and disordered eating behaviors among adolescents in Taiwan. Eat Behav. 2013;14(3):382-5. https://doi.org/10.1016/j. eatbeh.2013.05.002

PMid:23910785

28. Fredericks CA, Garcia K, Massey M, Vasagar, B, Borzekowski DL. Body image, eating disorders, and the relationship to adolescent media use. Pediatr Clin N Am. 2012;59(3):693-704. https://doi. org/10.1016/j.pcl.2012.03.017

PMid:22643174

29. Voelker DK, Reel JJ, Greenleaf C. Weight status and body image perceptions in adolescents: Current perspectives. Adolesc Health Med Ther. 2015;6:149-58. https://doi.org/10.2147/ahmt. s68344 PMid:26347007

30. Liu M, Wu L, Ming Q. How does physical activity intervention improve self-esteem and self-concept in children and adolescents? Evidence from a meta-analysis. PLoS One. 2015;10(8):e0134804. https://doi.org/10.1371/journal. pone.0134804

PMid:26241879

31. Stice E, Marti CN, Durant S. Risk factors for onset of eating disorders: Evidence of multiple risk pathways from an 8-yearprospective study. Behav Res Ther. 2011;49(10):622-7. https://doi.org/10.1016/j.brat.2011.06.009

PMid:21764035 